УДК: 811.163.41(091)

811.163.41:929 Белић А.

DOI: 10.18485/belic_slv.2016.1.ch11

Александар Милановић

\title{
ТЕОРИЈСКО-МЕТОДОЛОШКИ ОКВИР БЕЛИЋЕВЕ ПЕРИОДИЗАЦИЈЕ РАЗВОЈА СРПСКОХРВАТСКОГ ЈЕЗИКА
}

\section{1. Историјат питања: епоха појачаног интересовања за проблем} периодизације. Прву периодизацију развоја српског језика, засновану на анализи тада познатих писаних споменика, објавио је 1833. Павел Јозеф Шафарик у делу Serbische Lesekörner. ${ }^{1}$ Назнаке о потреби издвајања епоха у развитку српскога народног језика видљиве су и у радовима Миливоја Павловића из 30-их година 20. века, који су били на трагу Белићевих истраживања, нарочито у раду „Епохе развитка нашега језика и формирање дијалеката у историској перспективи” (Павловић 1937: 23-28). Веће интересовање за проблем периодизације појављује се, међутим, тек у другој половини 50-их и током 60-их година 20. века, када се у размаку од десетак година махом у југословенској периодици појављује више радова различитих аутора о епохама развоја не само српскохрватског већ и других јужнословенских језика: 1956. Миливој Павловић, 1958. Александар Белић, 1958. Рудолф Коларич, 1960. Иван Поповић, 1961-1962. Миливој Павловић, 1962. Јосип Хам, 1966. Павле Ивић, 1968. Светозар Манојловић. Србистика и сербокроатистика су у развоју ове дијахронијске методе, очигледно, касниле у односу на друге националне словенске филологије.

Значај који сеунаведеномпериодупридаваопроблемупериодизације огледао се и у неким мање видљивим научним детаљима. ${ }^{2}$ У овим радовима постављени су различити теоријско-методолошки оквири и

1 Актуелност овог пионирског научног подухвата огледа се у његовим резултатима и критеријалности: примењујући критеријуме везане за развој вокализма, Шафарик је преломним периодом у развоју схј. сматрао крај 14. века.

2 Као посебно илустративан може се узети садржај Јужнословенског филолога бр. XXIII (1958), у којем су објављени реферати са Првог конгреса југословенских слависта: прва два рада у њему, дакле радови на ударним позицијама часописа, посвећени су проблему периодизација јужнословенских језика (Белић 1958, Коларич 1958). 
примењени другачији аналитички и синтетички поступци, базирани на избору другачијих критеријума, па је сасвим разумљиво и што се резултати нису поклапали, а понегде су се чак и разилазили. ${ }^{3}$

Највећу научну полемику међу наведеним периодизацијама несумњиво је изазвала Белићева, па се у онима потоњим готово неизоставно налазила директна или скривена расправа са ставовима великог научника, везана првенствено за теоријско-методолошки оквир и критеријалност поделе на епохе и периоде. Као научно најподстицајнија периодизација из 50-их година, она и данас заслужује посебну научну пажњу, будући да је пресудно утицала на покретање неких суштинских питања везаних за дијахронијску србистику. То јој, уосталом, признају и ранији тумачи, који констатују како „možemo utvrditi da je ta periodizacija uz onu Vl. Georgieva izazvala u naučnim i širim krugovima veoma živ interes i lijepo priznanje" (Манојловић 1968: 50-51).

2. Синтеза Белићевих дијахронијских истраживања. Белић је своју периодизацију представио 1957, а објавио 1958, непосредно након што је дао коначан изглед Фонетици у Основима историје српскохрватског језика, ${ }^{4}$ и у време када је уобличавао и Речи са деклинацијом и Речи са конјугацијом, објављене постхумно $1962 .{ }^{5}$ У периодизацију су, дакле, интегрисана целокупна Белићева сазнања из дисциплине коју традиционално називамо историјском граматиком српског језика, тј. из њених поддисциплина којима је и са̂м, вођен интересовањима своје епохе, посветио највише пажње: историјској фонетици и историјској морфологији српског и српскохрватског језика. Јасно је да је до оваквог синтетичког рада, а свака периодизација је својеврсна синтеза, А. Белић морао доћи тек при рекапитулацији свих својих дијахронијских србистичких сазнања, изнетих у форми универзитетских уџбеника. У периодизацију је А. Белић, међутим, унео и извесне новине у односу на своја претходна истраживања: „Новина према ранијим погледима проф. Белића је полажење од најдубље перспективе словенске језичке заједнице” (Павловић 1961-1962: 51).

Рад има свега 11 и по страна основног текста, и страну и по резимеа на руском језику. Неуобичајено за Белићеве радове, у овоме нема фуснота нити позивања на било какву литературу. С друге стране, у односу према већини периодизација других аутора, Белићева доноси и до-

3 Ваљана упоредна анализа свих наведених периодизација није могућа у раду овога обима.

4 Из Предговора се види да је уџбеник завршен 1956, а штампан је 1960. године.

5 Белић је преминуо 26. фебруара 1960 (СЕ 2010: 685). 
датне информације о теоријско-методолошким поставкама, циљевима и критеријумима овог научног метода, и управо ће нас ове напомене, скрајнуте при каснијим тумачењима, водити ка објективнијем тумачењу вредности и актуелности Белићеве периодизације.

Централна теоријско-методолошка питања периодизације као научног поступка која је Белић покренуо могу се груписати на следећи начин:

a) питање утицаја „друштвених, економских и политичких прилика" на развитак језика;

б) питање циља и природе периодизације као научног метода;

в) питање критеријалности и објективности периодизације као научног метода.

3. Утицај „друштвених, економских и политичких прилика” на развитак језика. Уводни пасус рада, тј. најуочљивије место читавог текста, посвећен је питању којим су се тумачи и критичари Белићеве периодизације највише бавили - питању утицаја „друштвених, економских и политичких прилика" на развитак језика:

„Развитак језика иде паралелно са развитком друштвених, економских и политичких прилика једног народа. Тај је развитак наших народа био доста немиран, а каткада и врло буран. Стално су се дешавали поремећаји наших народних маса, каткада сношљивији за њихов развитак, а каткада и готово катастрофални" (Белић 1958: 3).

Већ на самом почетку рада А. Белић издваја и пресудни фактор међу онима које описује и анализира: чињеницу да су „друштвене, економске и политичке прилике" утицале на миграције становништва, које именује као „поремећаје наших народних маса” или „знатно померање становништва” и оцењује их као најзначајније за „промене дијалекатских односа". Белић, дакле, не игнорише друштвене факторе, али као релевантне узима само оне који су доводили до миграција. ${ }^{6}$ Процес селекције друштвених фактора водио га је до фокусирања на најбитније, којима се потом у анализи враћао у различитим контекстима: тако миграцијама као релевантном фактору језичких промена А. Белић посебну пажњу поклања у анализи петог периода (од 13. до краја 14. в.). Описујући

6 Битно је овде истаћи да други релевантни друштвени феномени - као што су проблем вероисповести говорника српског тј. српскохрватског језика и проблем односа говора урбане и руралне средине - који су утицали на фонетско-фонолошке процесе (нпр. губљење и чување фонеме /x/ или (не)вршење јекавског јотовања у групама /тj, дј/) у Белићевој периодизацији нису посебно апострофирани. 
на овоме месту потискивање чакавских говора на острва и на север и заузимање првобитно чакавских простора штокавским становништвом, Белић закључује: „Није место да се овде о томе даље расправља; али је и оволико довољно да покаже сву множину узрока због којих се кретање језичких црта толико из основа променило” (Белић 1958: 11).

И у закључку рада А. Белић комплетне резултате периодизације повезује управо са друштвеним факторима, уводећи у разматрање први и једини пут и појам државе. Подводећи осам периода у три велике епохе у закључку рада, аутор је овај синтетички поступак директно мотивисао тако што га је довео у везу управо са друштвено-историјским променама:

„I и II период представљају још историју наших народа изван Балканског Полуострва, од III-V периода - развитак на Балканском Полуострву од првог стварања наших засебних држава, њихове борбе и њихова цветања, дакле њихова позитивног развијања до доласка Турака, остала три периода VI, VII и VIII претстављају епоху тешке борбе са Турцима, потчињавања њима и других прилика које су се у вези са тим развиле, па затим и постепеног ослобођавања од њих. У границама сваког од тих раздобља било је и тешких поремећаја, и великих премештања наших народних маса и свега другога што је то пратило, чиме се одређује много штошта у образовању ових периода" (Белић 1958: 13).

Белић у раду није инсистирао на прецизнијем анализирању утицаја држава, средњовековних и каснијих, на језичке промене, очигледно проценивши да за такве анализе нема довољно употребљивог материјала нити у постојећим филолошким нити у историјским истраживањима. То му је врло конкретно замерено у потоњој литератури: „С̆ini nam se da je smanjena važnost naših srednjovjekovnih kneževina i državica i odgovarajućih historijskih faktora za širenje jezičkih crta, možda i metanastički faktor u srednjem vijeku" (Манојловић 1968: 51). У жељи да избегне научне произвољности и импровизацију које морају произаћи из недостатака чињеница, А. Белић је фактор средњовековних држава практично изоставио у раду, помињући их само у закључку, где уочава заокружени језички „развитак на Балканском Полуострву од првог стварања наших засебних држава, њихове борбе и њихова цветања, дакле њихова позитивног развијања до доласка Турака" (Белић 1958: 13). За право му, додајмо, дају скромни резултати до којих су стварајући своје периодизације на овом терену дошли потоњи историчари језика (И. Поповић, С. Манојловић, па и J. Хам), који су се при начелном опредељењу за анализу утицаја државног фактора на језик са прокламованог појма државе (нпр. средњовековне Рашке, Босне, Зете, Хума и сл.) по правилу пребацивали на географске, дијалектолошке и културолошке појмове попут: иентар 
и периферија (Поповић 2007: 302, Манојловић 1968: 67), прогресивни центар и конзервативна гранична подручја (Поповић 2007: 315) и сл. Нити у једном од Поповићевих закључака поглавља посвећених периодима развитка сх. језика не спомињу се државе, већ само, осим поменутих (лингво)географски појмови: север, југ итд. Манојловићеви закључци о утицају средњовековних држава на формирање наших дијалекатских типова потпуно су неубедљиви и непоткрепљени било каквим лингвистичким доказима (Манојловић 1968: 67-68).

Будући да је различите друштвене факторе Белић посебно подвукао и у уводу и у закључку рада, тј. у најзначајнијим деловима текста, на први поглед може изненадити реакција појединих имплицитних или експлицитних критичара Белићеве периодизације (И. Поповића, С. Манојловића), који су аутору замерали игнорисање управо утицаја друштвених промена на језичке: „Ipak i prof. Belić u izvjesnoj meri zanemaruje historijske i socijalne faktore koji idu paralelno s unutrašnjim jezičkim zakonima uzajamno se dopunjujući” (Манојловић 1968: 51). Разлог такве реакције објаснићемо у наредном поглављу.

4. Циљ и природа периодизације као научног метода. За разлику од М. Павловића, који је сматрао да периодизација не представља лингвистички метод већ резултате тог метода, ${ }^{7}$ А. Белић је периодизацију експлицитно одредио као тингвистички метод који помаже разумевању развитка језика:

„Периодизација је, као и сваки лингвистички метод, један од начина да се приближимо разумевању развитка неког језика. То, разуме се, не значи да ће то бити потпуна слика његова, али то несумњиво значи нарочито посматрање језичко, изван свих других фактора сем чисто језичких који се огледају у юегову развитку [истакао А. М.], иако се, наравно, тај развитак мора доводити у везу са свима осталим факторима" (Белић 1958: 4).

Уметнута конструкција, истакнута с наше стране, у овоме цитату очито је лоше протумачена код Белићевих критичара јер није уочено да се она не односи на саму анализу, већ на чисто лингвистичке резултаmе анализе, које потом у закључку ваља довести у везу са друштвеним факторима - баш као што је и учињено у Белићевом раду, и баш као што је наглашено у продужетку наведене реченице. Погрешној рецепцији Белићеве периодизације несумњиво је допринело и учитавање садржаја

7 „Свако груписање факата, а нарочито периодизација процеса у језичкој дијахронији, не представља метод, али представља резултате лингвистичких метода" (Павловић 1961-1962: 51). 
који је он унео, знатно раније (1939), у увод прве књиге капиталног дела $O$ језичкој природи и језичком развитку: „Каткада изгледа да је лингвистика постала део психологије, логике, филозофије или чак - социологије. Ово је испитивање далеко од тога. Ја сам се трудио - колико год сам могао - да ослободим и своје испитивање и своја размишљања од тих дисциплина тамо где им није место [истакао А. М.]” (Белић 1998: 25). Површним читањем и овог Белићевог исказа, без уочавања самога његовог краја који смо истакли, добијена је искривљена слика која је, очито, дуго опстала у лингвистици при рецепцији Белићеве научне, првенствено дијахронијске лингвистичке мисли.

Коначно, А. Белић је истакао и синтетичку природу периодизација, којима је циљ стварање што упрошћенијег, а тиме и прегледнијег, модела компликованог феномена језичких промена:

„Овако је изношење по неопходности и синтетично јер би детаљно расправљање о чињеницама знатно компликовало и учинило нејасним саму ствар; међутим то никако не значи да при изношењу тих чињеница треба занемарити њихов стварни значај и унутрашњи смисао" (Белић 1958: 4).

\section{5. Критеријалност и објективност периодизације као научног} метода. Питање селекције критеријума при изради периодизације А. Белић је довео у директну везу са тичношћу историчара језика, његовим знањем, искуством и способношћу да из обиља језичких процеса и података селектира најзначајније, не улазећи детаљније у строге научне параметре за тај избор:

„Свако овак[в]о изношење у знатној мери је индивидуално, јер је појмљиво да из множине чињеница које су од значаја за развитак језика морају бити изабране оне које су то у највећој мери, а то зависи од нашег схватања и осећања тежине самих чињеница" (Белић 1958: 4).

Ништа прецизнији у вези са проблемом критеријума при периодизацији Белић није био ни у закључку рада, у којем је видљиво само једно јасно мерило: распространеност језичких процеса. У закључку рада се опажа и како је А. Белић желео селектовати само процесе који су развоју језика давали „општу карактеристику”, не одређујући конкретно, међутим, ни њу саму:

„Ја сам овде изнео најкрупније црте којима се карактеришу поједини језички периоди. Наравно да има доста појединачних црта које су захватиле и веће просторије [просторе - прим. А. М.] наших дијалеката, али оне представљају унутрашње процесе наших говора који им нису давали општу карактеристику" (Белић 1958: 12). 
Недовољна Белићева прецизност при образлагању критеријума за селекцију података у периодизацији иницирала је почетак дискусије о овом питању у србистици: „Овакав став отвара пут за конструктивну дискусију, а нарочито у два правца: прво, утврђивање почетне границе историје српскохрватског језика; друго, усклађивање мерила датих по језичким појавама са 'свима осталим факторима', а то значи са узроцима процеса и са самим процесима" (Павловић 1961-1962: 52).

6. Кристализација кључних теоријско-методолошких питања историјске србистике. Белић је, дакле, у својој периодизацији допринео кристализацији двају теоријски и методолошки значајних питања историјске србистике, од којих је једно већ издвојено: а) питање времена генезе српскохрватског језика, али и б) питање „краја историје српскохрватског језика". Прво питање односи се на временске границе између прасловенског, прајужнословенског и српскохрватског језика, а друго на раздвајање „старог” од савременог српскохрватског језика.

По Белићевом мишљењу, „прасловенска епоха трајала је до краја IV в. наше ере”, док су „епоха јужнословенског јединства и почетак његова цепања трајали најмање стотину година", које смешта у време V-VI в. (Белић 1958: 5). У резимеу на руском језику Белић напушта формулацију о јужнословенском јединству и експлицитно пише о „јужнословенском прајезику”, док „II эпоха обозначает свободное развитие сербского и хорватского языков" (Белић 1958: 14). У самом раду он се експлицитно не одређује према питању именовања, али је очито да о „историји нашег језика" пише тек (или већ, посматрано из структуралистичког угла) у 3. периоду, који је трајао од VII до VIII в., тј. од досељавања на Балкан (Белић 1958: 6). У закључку, при конституисању епоха, он је избегао да прецизира питање именовања језика, баратајући појмом народ (Белић 1958: 13), али је из свега наведеног несумњиво да је Белић сматрао да српскохрватски језик постоји од VII века нове ере.

Са друге стране, последњи тј. осми период обухвата време XIX в. и чине га „различити перифериски појави у нашем језику” (Белић 1958: 12). Уколико сажмемо Белићеве ставове, историју српскохрватског језика пратимо у времену од VII до XIX в.

7. Селектирани подаци и нивои језичке структуре. До оваквих закључака А. Белић је дошао селектирањем језичких факата који су припадали двама језичким нивоима. У складу са погледима тадашње лингвистике и школе у којој се А. Белић развијао и формирао, издвојено је највише фонетско-фонолошких промена (укључујући и акценатске), али 
нису заобиђене ни најмаркантније промене у морфологији. Лексичкосемантичке и синтаксичке иновације нису узете у обзир.

7.1. За свих осам периода издвојене су карактеристичне фонетско-фонолошке промене, а у чак пет од њих (првом, трећем, четвртом, петом и осмом) оне су једине и регистроване. Тако је у првом периоду издвојена судбина група ${ }^{*} \mathrm{kvě,},{ }^{*} \mathrm{gvě,} \mathrm{као} \mathrm{и} \mathrm{група}{ }^{\star} \mathrm{dl}$, ${ }^{\star} \mathrm{tl}$; у другом судбина група ${ }^{\star} \mathrm{tj},{ }^{*} \mathrm{dj}$, као и процес ${ }^{*} \mathrm{~b}={ }^{\star} ъ$. У трећем периоду наглашава се формирање штокавице са две варијанте, а класификација је заснована опет на фонетском критеријуму (šć : št, žđ : žd). Издвојене су још две промене у основном језичком нивоу: једна акценатска (промена старог акута) и једна фонетско-фонолошка (е̌ > е иза дентала у чакавским говорима). Четврти период карактеришу: деназализација, изједначавање јерија са вокалом /i/, свођење полугласника на квалитативно нови /ə/, промена vә- > u-. У петом су опет издвојене само фонетско-фонолошке промене: вокализација полугласника (ә> а), те развој рефлекса (или чување) јата, вокалног /1/ и финалног /-1/. За шести период пак типична је појава узлазних акцената и губљење $/ \mathrm{h} /$, а за седми ново јотовање. Коначно, у последњем периоду све селектиране промене на периферији сх. језичке територије фонетско-фонолошке су природе (дифтонгизација и померање артикулације вокала, промене вокалске боје, промене артикулације и природе сугласника: цакавизам, -m > -п и сл.).

7.2. Морфолошке иновације издвојене су само у другом, шестом и седмом периоду. Други период карактерише појава наставка -ga код придева и заменица у ген. јд., потом наставка -то у 1. л. мн. презента и губљење -t у 3. л. јд. и мн. овог глаголског облика. У шестом периоду издвојена је појава /-â/ у наставку за ген. мн. именица и наставка у дат. и инстр. мн., а у седмом ширење другог наставка и на лок. мн., тј. стварање синкретизма трију множинских падежа. Видљиво је, дакле, да су морфолошке промене при избору сведене на минимум: у деклинацији је издвојена само једна заменичко-придевска иновација (наставак -ga) и две везане искључиво за множинске облике именица (-â у генитиву и -та у дативу-инструменталу-локативу); у читавој конјугацији селектиране су само промене у презенту.

7.3. Важно је овде истаћи да поједине веома важне процесе у историјској фонетици, фонологији и морфологији народног језика А. Белић није узео у обзир. Тако, на пример, није издвојио чак ни поједине процесе који су утицали на инвентар фонема, како вокалских (попут губљења вокалних $/ \mathrm{r}^{\prime} / \mathrm{i} / \mathrm{l}^{\prime} /$ ) тако и консонантских (попут појаве $/ \mathrm{f} /$ и $/ \mathrm{dž} /$, веларизације палатала и сл.). У историјској морфологији није помену- 
то значајно смањење деклинационих врста (пре свега именичких, али и заменичко-придевских), као ни мање изражено смањење конјугационих парадигми (потпуно губљење супина и партиципа и делимично губљење инфинитива, имперфекта, аориста и сл.).

Посебно је упечатљиво Белићево неспомињање судбине двојине у српскохрватском језику, кључне промене у граматичкој категорији броја којој је посветио читаву монографију, једну од најзначајнијих у словенској и светској лингвистици са овом тематиком. Можемо само претпоставити да је и у овом случају, као и у претходно поменутим, пресудила дуготрајност и постепеност овог морфолошког процеса, те немогућност да се прецизна хронологија утврди кроз стање посведочено у споменицима. Са̂м А. Белић о разлозима за ово изостављање релевантних процеса при стварању периодизације у раду није оставио било какво сведочанство.

8. Белићева терминологија у периодизацији. Иако је први рад на српском језику о периодима развитка схј. објавио Миливој Павловић 1956. године, термин периодизација у историју нашег језика увео је Белић 1958, дајући му описну дефиницију:

„Све је то [тј. „развитак друштвених, економских и политичких прилика" - прим. А. М.] давало у извесним временима и нарочиту слику најзнатнијих језичких особина којима се поједине епохе развитка нашег народа карактеришу. Иако те епохе имају заједничких црта, оне имају и својих разлика. Зато ћу покушати да их поделим у периоде" (Белић 1958: 3).

Поред термина периодизација, А. Белић је увео и термине епоха и период дате у хијерархијском односу. У функцији хијерархијски надређеног нашао се термин епоха, док је термин период њему подређен, те тако три епохе чине осам периода: прву епоху два периода (I, II), другу епоху три (III-V), као и трећу (VI-VIII).

Термин епоха већ је пре Белића употребљавао и М. Павловић. У Павловићевој периодизацији није било груписања временских одсека, те он у свим радовима пише само о епохама (Павловић 1937: 23, Павловић 1956: 12, Павловић 1961-1962: 61), не стварајући појмовну и терминолошку структуру са хиперонимима и хипонимима. Термине епоха и период користи и П. Ивић, али у другачијој функцији у односу на А. Белића: „У повести вокализма јасно се оцртавају две преломне епохе, једна у X-XI веку, а друга у XIV-XV. Можемо на основу тога разликовати три периода обележена одређеним структуралним одликама" (Ивић 1990: 63). Додајмо да је хијерархизацију термина поред А. Белића устројио и 
С. Манојловић: надрећени термин је етапа, која може садржати више периода (Манојловић 1968: 51).

9. Утицај Белићеве периодизације. Одраз Белићеве периодизације у потоњима био је експлицитан и имплицитан. Експлицитни утицаји видљиви су највише у периодизацији М. Павловића, који је с временом, до 1962. године, „potpuno usvojio Belićevu periodizaciju interpretirajući je veoma impresivno s posebnim naglaskom na procese miksoglotskog i miksodijalekatskog karaktera" (Манојловић 1968: 46). У првим радовима М. Павловић је писао о пет епоха у развитку нашег језика (Павловић 1956: 12), да би их потом, несумњиво под утицајем Белићеве периодизације, свео на три (Павловић 1961-1962: 52-53).

Имплицитни утицај видљив је, између осталих, и у периодизацији П. Ивића, а представљен је у форми скривене полемике о критеријумима која се налази на почетку рада (Ивић 1990: 61-62). Ту је П. Ивић истакао „неподударности критерија” у постојећим периодизацијама и одбацио, не именујући аутора, Белићево решење селектирања иновација са различитих језичких нивоа, определивши се за одабир промена у фонолошком систему.

10. Домети и ограничења Белићеве периодизације. Белићева периодизација представља најбољи доказ о стању дијахронијске лингвистике код Срба средином 20. века. Овај рад био је истовремено веома инспиративан за даља истраживања у потрази за заокруженим периодима у развоју српског и српскохрватског језика, о чему најбоље сведоче потоње периодизације, али је научној јавности представио и ограничења предструктуралистичких модела анализе и синтезе промена у језику.

10.1. Међу несумњиве врлине ове периодизације ваља уврстити податак да је у њој први пут јасно и прецизно дефинисано питање значаја друштвених, економских и политичких фактора на промене у српскохрватском народном језику, као и да су истовремено дате и смернице у тражењу одговора на ово питање. Као релевантни издвојени су они друштвени фактори који су доводили до миграција, док је фактор утицаја држава остављен по страни. У структури са три епохе и осам периода као кључни спољашњи фактор показале су се велике сеобе становништва, а анализа стања у споменицима указала је да су језичке промене у нераскидивој корелацији са друштвеним. Вредновање изнетих резултата - дато кроз паралелу са резултатима најрелевантније позније, Ивићеве структуралистичке периодизације (израђене на чврстом фонолошком критеријуму развоја вокализма) - у доброј мери Белићевим временским 
границама даје за право, и то барем у оном делу где се констатује како je XIV в. један од преломних периода у развоју нашега народног језика, који је означио крај читаве епохе и улазак у нову.

10.2. Кључне ограничености Белићеве периодизације везане су за чињеницу да је у њој наведен скуп изолованих језичких промена на различитим нивоима система: фонетско-фонолошком (укључујући и акценатски тј. прозодијски) и морфолошком. Иако је Белић био упознат са тада већ актуелним структурализмом (уп. нпр. Белић 1998: 30), између језичких промена у његовој периодизацији нису уочене корелације нити у оквиру језика као хијерархијски устројеног система нити у оквиру његових подсистема. Такође, корелације нису успостављене нити у оквирима периода и епоха нити између ових временских одсека. Неувиђање повезаности између језичких промена, нарочито оних на фонетско-фонолошкој равни, остао је највећи недостатак Белићевог приступа. Временску и структурну повезаност између језичких промена убрзо после Белићеве периодизације увидео је и презентовао П. Ивић у свом структуралистичком моделу периодизације (Ивић 1990).

Највећа мана Белићеве периодизације плод је ограничења предструктуралистичког приступа анализи језичких промена. Она, дакле, не представља огрешење или пропуст научника већ пре илуструје ограниченост читаве научне епохе којој је припадао: „Проблем периодизације историје српскохрватског језика и досад је привлачио пажњу истраживача. У најновије време изложени су различити погледи на ту проблематику. Упркос очигледној неподударности критерија, па према томе и закључака, свим тим покушајима заједничка је једна одлика: они се не ослањају на историју језичког система као таквог" (Ивић 1990: 61).

11. Закључак. У савременој дијахронијској србистици, па и настави на универзитетима, помало су запостављени резултати научног метода који је током 50-их и 60-их година битно допринео развоју ове научне дисциплине - периодизације. Како трагова периодизације нема у Белићевим уџбеницима (Белић 1999а), створен је погрешан и површан утисак да највећем српском лингвисти прве половине 20. века до овог метода није било превише стало.

У раду о периодизацији, напротив, огледа се Белићев заокружен поглед на историју српскохрватског језика. Синтетички приступ оголио је процесе које је А. Белић сматрао круцијалним за језички развитак и показао како их је аутор груписао, а потом у закључку довео у везу са друштвеним променама. Рецепција Белићевог рада из 1958. несумњиво 
је послужила као директни „окидач” барем за неке од радова сличне амбиције који су уследили у наступајућој епохи. У њима се традиционални теоријско-методолошки оквир анализе већ почео прво сукобљавати, а затим и повлачити пред структуралистичким, који је кроз рад П. Ивића убедљиво демонстрирао предности нових приступа у дијахронијској лингвистици.

ИЗВОР

Белић 1958: Александар Белић, „Периодизација српскохрватског језика”, Јужнословенски филолог, XXIII, 1-4, 3-15.

\section{ЛИТЕРАТУРА}

Белић 1998: Александар Белић, Опита лингвистика, Изабрана дела Александра Белића, том 1, Београд: Завод за уџбенике и наставна средства.

Белић 1999а: Александар Белић, Историја српског језика : фонетика, речи са деклинацијом, речи са конјугацијом, Изабрана дела Александра Белића, том 4, Београд: Завод за уџбенике и наставна средства.

Белић 1999б: Александар Белић, Историја српског језика : студије, расправе, чланци, Изабрана дела Александра Белића, том 7, Београд: Завод за уџбенике и наставна средства.

Ивић 1990: Павле Ивић, О језику некадашюем и садашюем, Београд -Приштина: БИГЗ - Јединство.

Коларич 1958: Rudolf Kolarič, „Periodizacija razvoja slovenskega jezika”, Јужнословенски филолог, XXIII, 1-4, 17-21.

Манојловић 1968: Svetozar N. Manojlović, „Glavne etape u razvitku hrvatskosrpskog jezika”, Radovi. Razdio lingvističko-filološki (4), 1965/1966, 1967/1968, Zadar, 46-69.

Павловић 1937: Миливој Павловић, „Епохе развитка нашега језика и формирање дијалеката у историјској перспективи”, у: Проблеми језика и народне културе, Скопље: Штампарија Василија Димитријевића, 23-28.

Павловић 1956: Миливој Павловић, Примери историског развитка српскохрватског језика, Београд: Научна књига.

Павловић 1961-1962: Миливој Павловић, „Услови развитка и периодизација историје српскохрватског језика", Јужнословенски филолог, XXV, 49-63. 
Поповић 1960: Ivan Popović, Geschichte der serbokroatischen Sprache, Wiesbaden.

Поповић 2007: Иван Поповић, Историја српскохрватског језика, Београд Крагујевац: Лира - Требник - Елвод принт.

CE 2010: Српска енциклопедија, Том I, Књига 1, А-Беоб, Нови Сад - Београд: Матица српска - САНУ - Завод за уџбенике.

Хам 1962: Josip Hamm, „Zur Periodisierung der südslavischen Sprachen”, Wiener slawistisches Jahrbuch, IX, 5-31.

Aleksandar Milanović

THEORETICAL AND METHODOLOGICAL FRAMEWORK OF BELIĆ'S PERIODIZATION OF THE DEVELOPMENT OF SERBO-CROATIAN LANGUAGE

Summary

The paper tackles the advantages and shortcomings of Belićs view on the periodization of the evolution and development of Serbo-Croatian. The study highlights the issue of the social aspect and its impact on language changes. Belićs periodization is positioned in the context of other periodizations and compared against them. As a result, the effects that this periodization had on the methodology in diachronic Serbian studies are identified and evaluated. Belićs complete overview of the history of Serbian is reflected in his essay on periodization. Synthetic approach reveals the processes which Belić considered crucial for language development indicating the way the author classified such processes having related them to various social changes. 